\title{
Comparative chemical investigations of alum treated archaeological wood from various museum collections
}

\author{
Jeannette Jacqueline Łucejko ${ }^{1,2^{*}}$, Caitlin M. A. McQueen ${ }^{2}$, Malin Sahlstedt ${ }^{2,3}$, Francesca Modugno ${ }^{1,2}$, \\ Maria Perla Colombini ${ }^{1,2}$ and Susan Braovac ${ }^{2}$
}

\begin{abstract}
From the mid-1800s to the late 1960 s, conservation by alum salts $\left(\mathrm{KAl}_{(}\left(\mathrm{SO}_{4}\right)_{2} \cdot 12 \mathrm{H}_{2} \mathrm{O}\right.$ - potassium aluminium sulphate), using various recipes, was a common method to prevent shrinkage and to strengthen waterlogged archaeological wooden objects. This method was mainly used in Scandinavia. The alum method appears to have also been applied to highly degraded archaeological waterlogged wood in other countries, for example in the U.S and Germany. Today, many of the archaeological wooden objects treated with alum show extreme deterioration and very low pH, which are attributed to the effects of the alum-treatment. This study investigated the extent of the current levels of chemical degradation in wooden objects conserved with alum salts at different points in time (1880s, 1930s and 1905-13) in order to understand their current condition and whether extent of degradation was in any way related to time of treatment, in an attempt to understand the rate of degradation. It was also an opportunity to compare the chemical state of preservation of alum-treated wood from different collections, as only the Oseberg collection has been intensively studied in this way up until now. Samples from historical wooden objects from the following collections were investigated and compared: the Dejbjerg collection (National Museum of Denmark in Copenhagen); the Oseberg collection (Museum of Cultural History, Oslo, Norway); the Glimmingehus collection (Swedish History Museum, Sweden). Analyses of lignocellulosic polymers and of inorganic compounds were undertaken to evaluate the chemical preservation of the wooden objects. The investigations were performed using a multi-analytical approach which consisted of: pH measurements, analytical pyrolysis (Py-GC/MS), X-ray diffraction (XRD) and scanning electron microscopy with energy-dispersive $X$-ray spectroscopy (SEM-EDS). It was possible to link the extent of degradation with time, on a general level but we found a great variability in the state of preservation of the wood also within the same collection. It is clear, however that alum-treated wood is more degraded than archaeological wood not treated with alum.
\end{abstract}

Keywords: Archaeological wood, Alum treatment, State of degradation, pH, Py-GC/MS, SEM-EDS, XRD

\section{Introduction}

From the mid-1800s until the 1950s, and in some cases up to the 1960s, aluminium potassium sulphate (alum) was routinely used for the conservation of waterlogged wooden objects of an archaeological and historical value.

\footnotetext{
*Correspondence: jeannette.lucejko@unipi.it

1 Department of Chemistry and Industrial Chemistry, University of Pisa, via Moruzzi 13, 56124 Pisa, Italy

Full list of author information is available at the end of the article
}

In the 1960 s it was eventually replaced with polyethylene glycol (PEG), as PEG-treated wood was less brittle. The alum conservation method was simultaneously developed in Denmark and Germany in the 1850s and in 1861 both methods were published $[1,2]$. It was one of the first methods used for the conservation of highly deteriorated waterlogged wood artefacts.

The alum treatment method consisted of immersing waterlogged wooden fragments into a concentrated solution of alum at $90{ }^{\circ} \mathrm{C}$ from 2 to $24 \mathrm{~h}$ or more [3]. The

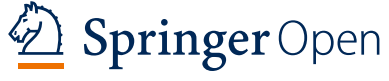

(c) The Author(s) 2021. This article is licensed under a Creative Commons Attribution 4.0 International License, which permits use, sharing adaptation, distribution and reproduction in any medium or format, as long as you give appropriate credit to the original author(s) and the source, provide a link to the Creative Commons licence, and indicate if changes were made. The images or other third party material in this article are included in the article's Creative Commons licence, unless indicated otherwise in a credit line to the material. If material is not included in the article's Creative Commons licence and your intended use is not permitted by statutory regulation or exceeds the permitted use, you will need to obtain permission directly from the copyright holder. To view a copy of this licence, visit http://creativeco mmons.org/licenses/by/4.0/. The Creative Commons Public Domain Dedication waiver (http://creativecommons.org/publicdomain/ zero/1.0/) applies to the data made available in this article, unless otherwise stated in a credit line to the data. 
solution penetrated the porous structure of the wooden objects and replaced the water. With cooling after impregnation, the alum crystallized, absorbing some of the water as crystallization water. The treatment penetrated the outermost $5 \mathrm{~mm}$ surface of the wood across the grain and about $5 \mathrm{~cm}$ along the grain, with the result of reducing shrinkage during drying. Wood deeper below the surface did not contain as much alum and had developed many voids during treatment, likely caused by osmotic shock due to the high concentrations used in the impregnation baths. The method resulted in wood which was very brittle.

To reduce brittleness, earlier versions of the method included the application of linseed oil to surfaces after alum impregnation [3, 4]. After 1911, glycerol was added to the treatment bath, first implemented by George Rosenberg at the National Museum of Denmark [5]. The addition of this highly hygroscopic compound made the wood extremely vulnerable to fluctuations in ambient humidity [6]. Irrespective of when the treatment was carried out, other materials that were commonly applied to wooden objects after the alum treatment included melted beeswax, shellac or nitrocellulose varnishes [7].

Today many of the wooden objects treated with alum show extreme deterioration due to very low $\mathrm{pH}$ (below 2) which are attributed to the effects of the alum-treatment itself $[8,9]$. The method causes the release of sulphuric acid during the heating phase, according to the following reaction [10]: recently applied as a double catalyst to convert simple sugars to hydroxymethylfurfural, via dehydration and isomerization [16]. Other works have found evidence of aluminum-catalysed hydrolysis of cellulose in paper treated with aluminum salts [17-19].

Similar chemical reactions to those described above from the literature likely occurred in the archaeological wood during alum treatment. Furthermore, the sulphuric acid generated through heating was also likely absorbed by the wood and has stayed within it ever since. In the Oseberg wood, recent analyses have shown that cellulose and hemicellulose are highly depolymerized and that lignin is oxidized [8].

In Scandinavia, wooden objects recovered before the 1950s or even 1960s were very likely treated with alum salts if they were highly degraded during burial. Such objects probably number into the thousands. To date, most of the information about chemical degradation of alum-treated wood comes from studies performed on the Oseberg collection [3, 8-10, 20].

The aim of this study was to investigate the extent of chemical degradation in alum-treated wooden objects from two additional collections in order to broaden our insight into degradation patterns in this material, and to identify the range of potential additives that may not have been mentioned in original treatment records.

Samples were collected from objects taken from three Scandinavian collections: the Dejbjerg collection, treated in the late 1880s (National Museum of Denmark in

$$
3 \mathrm{KAl}\left(\mathrm{SO}_{4}\right)_{2}+12 \mathrm{H}_{2} \mathrm{O} \rightarrow \mathrm{KAl}_{3}\left(\mathrm{SO}_{4}\right)_{2}(\mathrm{OH})_{6} \downarrow+2 \mathrm{~K}^{+}(\mathrm{aq})+4 \mathrm{SO}_{4}^{2-}(\mathrm{aq})+6 \mathrm{H}_{3} \mathrm{O}^{+}(\mathrm{aq})
$$

The current level of deterioration observed in alumtreated wood is likely related to both acid hydrolysis and the catalytic activity of aluminum ions in aqueous solution in the presence of sulphuric acid. Studies of the hydrolysis of polysaccharides through the use of dilute sulphuric acid have been reported in the literature, however the described experiments were carried out at higher temperatures $\left(170-190{ }^{\circ} \mathrm{C}\right)$ [11] than those applied during the treatment with alum $\left(90{ }^{\circ} \mathrm{C}\right)$. Aluminum salts (aluminum chlorate, aluminum sulphate) have been reported to catalyze the degradation processes of polysaccharides at high temperatures [12-14]. The use of strong acid (such as sulphuric acid or other strong acid with $\mathrm{pH}$ below 2) in the presence of a metal salt (as aluminium sulphate, aluminium chloride or other) to catalyze the hydrolysis of hemicelluloses and cellulose in lignocellulosics to glucose, was reported in the literature as a procedure at an industrial level, where strong acid helps to lower the hydrolytic activation energy of cellulose (i.e. temperature) [15]. Potassium alum has been
Copenhagen), the Oseberg collection, treated in the early 1900s (Museum of Cultural History, Oslo, Norway) and the Glimmingehus collection, treated in the 1930s (Swedish History Museum, Lund).

We were also interested if extent of chemical degradation could be related to time of treatment, in order estimate the remaining lifetime of the alum-treated Oseberg collection. To preserve it for future generations, we are currently planning preservation strategies. Achieving a better understanding of the approximate remaining lifetime of an alum-treated collection would indicate whether immediate measures, such as retreatment, were required-with all the risks of damage involved-or whether we could devote more time to research potential preventive conservation measures or refine existing retreatment methods in order to reduce risks of potential damage. We are aware that estimations of remaining lifetime is a complex undertaking, which is not well suited on small numbers of samples, as in the case here, but we nonetheless had this in mind during this study. 
This work represents the first chemically-based comparison of three different sets of archaeological wooden objects treated with alum. The same multi-analytical protocol and instrumentation were used for all samples, which included $\mathrm{pH}$ measurements, analyses by analytical pyrolysis coupled with gas chromatography and mass spectrometry (Py-GC/MS), X-ray diffraction (XRD) and scanning electron microscopy with energy-dispersive $\mathrm{X}$-ray spectroscopy (SEM-EDS). Analytical pyrolysis was applied to assess the state of preservation of the main wood components as well as to identify organic additives used during or after treatment with alum, as original treatment reports are not always complete. Inorganic components of analyzed material were investigated by XRD and SEM-EDS.

We expect that the knowledge acquired during this work will broaden our understanding of alum-treated wood as a material, which in turn will allow us to develop appropriate strategies for their long-term preservation, be it through retreatment or by other means.

\section{Materials and methods Materials}

The archaeological wood fragments from the three museum collections were treated with alum salt at different times: the Dejbjerg collection (1883), the Oseberg collection (1905-13) and the Glimmingehus collection (1936). The analysed samples are listed in Table 1 and objects are shown in Additional file 2: Figures S1-S18. Two Danish samples were taken from just below the surface and from the core (D-D1626 and D-E1622). Archival material (treatment records) informed about whether additional conservation materials had been used during or after treatment. For instance, two of the samples from the Norwegian collection were taken from wooden fragments known to be coated with linseed oil after alum treatment (N-207). Norwegian samples $\mathrm{N}-250-\mathrm{K}$ and $\mathrm{N}-250-\mathrm{F}$ were sampled from regions below the surface to avoid linseed oil. For some objects from the Swedish collection, museum documents registered the addition of glycerol in the alum bath, post-treatment with linseed oil, and for two of them even re-treatment with polyethylenglycol (PEG) in the 2000s, as described in Table 1.

As reference samples, both fresh undegraded and untreated archaeological wood samples were used. Fresh undegraded wood references included one softwood (ref pine) and two diffuse porous hardwoods (ref. maple, ref. birch). The untreated archaeological softwood reference sample is a medieval pine wood (arch pine) recently excavated from Medieval Oslo in 2018, donated from NIKU (Norsk institutt for kulturminneforskning). This wood was received in the waterlogged state and then freeze dried. Among the Oseberg finds, only the poorly preserved woods were treated with alum. However untreated archaeological reference samples were nonetheless possible to obtain from two objects in the Oseberg collection, an animal head post (C55000/1241904.138) and sled pull (C55000/17-1903.19), see Table 1. These objects were recovered in a poor state of preservation in 1904, but did not undergo alum treatment due to their extremely fine surface carvings as it was known that the alum method caused fine details to be blurred [21]. They were stored in water until an appropriate treatment was found. The sled pull was treated in the 1950s using tertiary butanol followed by freeze drying [22]. In this method, the tertiary butanol sublimates, leaving behind an unconsolidated wood structure. This object was coated with an acrylic resin, which did not penetrate deeply into the wood. The sample $(\mathrm{N}-17)$ originates from a flake of wood dislodged from the inner parts of the object, and as such did not contain the acrylic material used on the surface. The animal head post remained untreated as it had been damaged when its water tank leaked during the 1940s. After drying it was placed into storage. Although it was used to test surface coatings in the 1950 s, the sample analysed here $(\mathrm{N}-124)$ originated from the inner part of the object.

We are aware that different wood genera have different resistance to degradation but in the case of wood coming from different museum collections, it is not always possible to identify wood genus, as sample size is restricted. The available information is often limited to whether the material is a softwood or hardwood type. Hardwoods are described according to the distribution pattern of vessel elements (ring porous or diffuse porous).

The samples investigated are described in Table 1, which includes details about the treatment from archival documents and the $\mathrm{pH}$ values determined by applying damp $\mathrm{pH}$ strips to object surfaces.

\section{Apparatus}

The investigations were performed using a multianalytical approach involving $\mathrm{pH}$ measurements, analytical pyrolysis coupled with gas chromatography and mass spectrometry (Py-GC/MS), X-ray diffraction (XRD) and scanning electron microscopy with energy-dispersive X-ray spectroscopy (SEM-EDS).

\section{Py-GC/MS}

Analytical pyrolysis coupled with gas chromatography and mass spectrometry was used and the instrumental conditions are described in [20,23]. Approximately $100 \mu \mathrm{g}$ of each sample, previously ground in a ball mill (Pulverisette 23, Fritsch GmbH, Germany) if necessary, was placed into a stainless steel cup with $2.0 \mu \mathrm{L}$ of the derivatizing agent hexamethyldisilazane (HMDS) and 
Table 1 Sample names, treatment, additives listed in treatment records and surface pH values

\begin{tabular}{|c|c|c|c|c|c|}
\hline Collection & Sample & Wood type ${ }^{c}$ & Sampled area & $\begin{array}{l}\text { Treatment/additives noted in } \\
\text { laboratory reports }\end{array}$ & $\mathrm{pH}^{\mathrm{a}}$ \\
\hline \multirow{8}{*}{$\begin{array}{l}\text { Dejbjerg, (D) treated in 1883, National } \\
\text { Museum of Denmark, Copenhagen } \\
\text { (Denmark) }\end{array}$} & D-A1624 & Diffuse porous HW & Outer & Alum & 3.0 \\
\hline & D-B1624 & Ring porous HW & Outer & Alum & 2.0 \\
\hline & D-C1628 & Diffuse porous HW & Outer & Alum & 3.0 \\
\hline & D-D1626-A & Ring porous HW & Inner core & Alum & 3.5 \\
\hline & D-D1626-B & Ring porous HW & Outer & Alum & 3.5 \\
\hline & D-E1622-A & Ring porous HW & Inner core & Alum & 3.5 \\
\hline & D-E1622-B & Ring porous HW & Outer & Alum & 4.0 \\
\hline & D-F1629 & Diffuse porous & Outer & Alum & 3.5 \\
\hline \multirow{6}{*}{$\begin{array}{l}\text { Oseberg (N) treated between } 1904 \text { and } \\
1913 \text { Museum of Cultural History, Oslo } \\
\text { (Norway) }\end{array}$} & N-187D & $\mathrm{HW}$ & Dark part & Alum & 1.5 \\
\hline & N-187L & HW & Light part & Alum & 1.5 \\
\hline & N-207-A & Diffuse porous HW & Inner core & Alum, linseed oil & 2.5 \\
\hline & N-207-B & Diffuse porous HW & Outer & Alum, linseed oil & 2.5 \\
\hline & $\mathrm{N}-250 \mathrm{~F}$ & Diffuse porous HW & Middle & Alum & 1.5 \\
\hline & $\mathrm{N}-250 \mathrm{~K}$ & Diffuse porous HW & Inner alum-poor & Alum & 2.5 \\
\hline \multirow{8}{*}{$\begin{array}{l}\text { Glimmingehus (S) treated in } 1936 \text { Swed- } \\
\text { ish History Museum, (Sweden) }\end{array}$} & S-5T & HW & Outer & Alum, linseed oil & 3.0 \\
\hline & S-125h & HW & Outer & Alum, retreated with $\mathrm{PEG}{ }^{\mathrm{b}}$ & 4.5 \\
\hline & S-125k & HW & Outer & Alum & 3.5 \\
\hline & S-346 & HW & Outer & $\begin{array}{l}\text { Alum, glycerol, linseed oil retreated } \\
\text { with PEG }{ }^{b}\end{array}$ & 4.5 \\
\hline & S-346d & SW & Outer & Alum & 2.5 \\
\hline & S-346e & SW & Outer & Alum & 2.5 \\
\hline & S-383 & HW & Outer & Alum, linseed oil, glycerol & 1.5 \\
\hline & S-383C & $H W$ & Outer & Alum, linseed oil, glycerol & 1.5 \\
\hline \multirow[t]{3}{*}{ Reference archaeological } & Head post N-124 & Maple & Inner core & Untreated & - \\
\hline & Finest sled pull N-17 & Maple & Inner core & Untreated & - \\
\hline & Arch pine & Pine & Inner core & Untreated & - \\
\hline \multirow[t]{3}{*}{ Reference fresh undegraded } & Ref. maple & Maple & & Untreated & - \\
\hline & Ref. birch & Birch & & Untreated & - \\
\hline & Ref. pine & Pine & & Untreated & - \\
\hline
\end{tabular}

${ }^{a}$ Surface $\mathrm{pH}$ measurements were taken directly on object surfaces by applying damp $\mathrm{pH}$ strips. $\mathrm{pH}$ of reference sound maple is 5.5 . $\mathrm{pH}$ for samples head post $\mathrm{N}-124$ and finest sled pull N-17 was not measured

${ }^{\text {b }}$ Samples were re-treated with PEG 2000 between 2005 and 2009

'The wood genus is included only when it is confirmed by light microscopy. Hard wood is abbreviated as HW. Softwood is abbreviated as SW

placed in the micro-furnace at $550{ }^{\circ} \mathrm{C}$ of the type MultiShot Pyrolyzer EGA/Py-3030D (Frontier Lab) coupled with a 6890 gas chromatograph (Agilent Technologies, USA) and with an Agilent 5973 Mass Selective Detector operating in electron impact mode (EI) at $70 \mathrm{eV}$.

The pyrolysis products were identified using the Wiley and NIST libraries and the literature [24-26]. Automated Mass Spectral Deconvolution and Identification System software (AMDIS) [27] was used to integrate the pyrolytic peaks derived from the lignin and holocellulose wood components. Semi-quantitative calculations were performed as described by Tamburini [28]. The normalized values of the areas of the chromatographic peaks corresponding to 79 known pyrolysis products derived from holocellulose (i.e. combined cellulose and hemicellulose) and lignin (Table 2) were subjected to semiquantitative calculation. To estimate the extent of wood degradation, the relative amounts of wood pyrolysis products were used to calculate (a) the relative content of wood components, holocellulose and lignin, (b) the pyrolytic $\mathrm{H} / \mathrm{L}$ index (the ratio between the holocellulose (H) and lignin (L) content based on Py-GC/MS chromatographic areas) [29,30]; and (c) the distribution of lignin and holocellulose pyrolysis products divided into categories based on their chemical structure as described in [28] and shown in Table 2.

Since sampling from archaeological wood is highly restricted, the relative standard deviation of the 
Table 2 Holocellulose and lignin pyrolysis products by category

\begin{tabular}{|c|c|}
\hline Pyrolysis products from wood & Category \\
\hline \multicolumn{2}{|l|}{ Holocellulose pyrolysis products ${ }^{\mathrm{a}}$} \\
\hline $\begin{array}{l}\text { 2-Hydroxymethylfuran (TMS), 3-hydroxymethylfuran (TMS), 2-furancarboxylic acid (TMS), 2,3-dihydrofuran-2,3-diol (2TMS), 2-furyl- } \\
\text { hydroxymethylketone (TMS), 5-hydroxymethyl-2-furaldehyde (TMS) }\end{array}$ & Furans \\
\hline $\begin{array}{l}\text { 1-Hydroxy-1-cyclopenten-3-one (TMS), 2-hydroxy-1-cyclopenten-3-one (TMS), Z- and E-2,3-dihydroxy-cyclopent-2-enone (TMS), } \\
\text { 2-hydroxymethyl-3-methy-2-cyclopentenone (TMS), 1-hydroxy-2-methyl-1-cyclopenten-3-one (TMS), 1-methy-2-hydroxy-1-cy- } \\
\text { clopenten-3-one (TMS), 2-methyl-3-hydroxymethyl-2-cyclopentenone (TMS), Z-and E-2,3-dihydroxy-cyclopent-2-enone (2TMS), } \\
\text { 3-hydroxy-2-hydroxymethyl-2-cyclopentenone (2TMS), 3-hydroxy-2-(hydroxymethyl) cyclopenta-2,4-dienone (2TMS) }\end{array}$ & Cyclopentenones \\
\hline $\begin{array}{l}\text { 3-Hydroxy-(2H)-pyran-2-one (TMS), 3-hydroxy-(4H)-pyran-4-one (TMS), 5-hydroxy-2H-pyran-4(3H)-one (TMS), 3-hydroxy-6-methyl- } \\
\text { (2H)-pyran-2-one (TMS), 2-methyl-3-hydroxy-(4H)-pyran-4-one (TMS), 2-hydroxymethyl-2,3-dihydropyran-4-one (TMS), 3,5-dihy- } \\
\text { droxy-2-methyl-(4H)-pyran-4-one (2TMS), 2-hydroxymethyl-5-hydroxy-2,3-dihydro-(4H)-pyran-4-one (2TMS), 2,3,5-trihydroxy- } \\
\text { 4H-pyran-4-one (3TMS) }\end{array}$ & Pyranones \\
\hline 1,2,3-Trihydroxybenzene (3TMS), 1,2,4-trihydroxybenzene (3TMS), 1,2-dihydroxybenzene (2TMS), 1,4-dihydroxybenzene (2TMS) & Hydroxybenzenes \\
\hline $\begin{array}{l}\text { 1,4-Anydro-D-galactopyranose (3TMS), 1,6-anydro-beta-D-glucopyranose (3TMS), 1,4-anhydro-D-glucopyranose (3TMS), 1,6-any- } \\
\text { dro-beta-D-glucofuranose (3TMS) }\end{array}$ & Anhydrosugars \\
\hline \multicolumn{2}{|l|}{ Lignin pyrolysis products ${ }^{\mathrm{a}}$} \\
\hline $\begin{array}{l}\text { 4-Methylcatechol (2TMS), 3-methoxy-1,2-benzenediol (2TMS), 5-propyl-3-methoxy-1,2-benzenediol (2TMS), trihydroxy cinnamic } \\
\text { alcohol (3TMS), 3,4-dihydroxy cinnamyl alcohol (3TMS), 2-methoxy-3,4-dihydroxy cinnamic alcohol (3TMS) }\end{array}$ & Demeyhylated \\
\hline Coumaryl alcohol (2 TMS), Z and E coniferyl alcohol (2TMS), Z and E sinapyl alcohol (TMS) & Monomers \\
\hline $\begin{array}{l}\text { o-, m-, p-Cresol (TMS), phenol (TMS), guaiacol (TMS), vinyl phenol (TMS), 4-methylguaiacol (TMS), 4-ethylguaiacol (TMS), syringol } \\
\text { (TMS), 4-vinylguaiacol (TMS), 4-ethylcatechol (2TMS), 4-methylsyringol (TMS), 4-ethylsyringol (TMS), 4-vinylsyringol (TMS) }\end{array}$ & Short chain \\
\hline Eugenol (TMS), vanillyl alcohol (2TMS), propenyl-syringol (TMS), vanillylpropanol (2TMS), syringylpropanol (2TMS) & Long chain \\
\hline $\begin{array}{l}\text { p-Hydroxy benzaldehyde (TMS), vanillin (TMS), acetovanillone (TMS), syringaldehyde (TMS), acetosyringone (TMS), coniferylalde- } \\
\text { hyde (TMS), sinapylaldehyde (TMS), benzoic acid TMS, 4-hydroxy benzoic acid (2TMS), 3-hydroxy-4-methoxybenzenepropanoic } \\
\text { acid (2TMS), vanillic acid (2TMS), syringic acid (2TMS), coumaryl acid (2TMS), 3,4-dihydroxy-5-methoxy benzoic acid (3TMS) }\end{array}$ & Oxidised \\
\hline
\end{tabular}

${ }^{a}$ The number of trimethylsilyl groups (TMS) attached to the pyrolysis products is given in parentheses

measurements was calculated only on samples from fresh undegraded wood samples. The relative standard deviation obtained is $8 \%$ which is in accordance with the literature [24-26, 28].

The results obtained for alum-treated archaeological wood samples were compared with each other and with both sound woods and untreated archaeological wood references.

Analytical pyrolysis cannot distinguish pyrolysis products from cellulose and hemicelluloses, as the thermal degradation process forms the same pyrolysis products from the two types of polymers. This means that the method applied in this study cannot reveal the details of the chemical changes observed specifically in cellulose and hemicelluloses but rather refers to the chemical changes occurring in the overall polysaccharide fraction (holocellulose).

\section{$X R D$}

Analyses were performed using a PANalytical Empyrean Series 2 diffractometer with radiation $\mathrm{CuK} \alpha=1.54 \AA$, operating at $45 \mathrm{kV}, 40 \mathrm{~mA}, 2 \theta$ range $8-70^{\circ}$, step size $0.03^{\circ}$, time per step ranging between 997 and $4997 \mathrm{~s}$, equipped with a PIXcel ${ }^{1 \mathrm{D}}$ (Medipix3) detector. Samples were ground into a fine powder, and the powder spread to cover a $1.5 \mathrm{~cm}$ diameter sample holder. The HighScore
Plus suite was used for data analyses [31]. Measurements were performed using a reflection-transmission spinner and a zero background sample holder. Crystalline phases were identified using the ICDD-2016 database.

\section{SEM-EDS}

Powdered samples were placed directly onto carbon tape and analyses were performed using a FEI Quanta 450 Scanning Electron Microscope coupled with an Oxford $\mathrm{X}-\mathrm{Max}^{\mathrm{N}} 50 \mathrm{~mm}^{2}$ detector, using the low vacuum mode to avoid charging and a voltage of $20 \mathrm{kV}$. The other parameters (spot size, pressure, and working distance) were modified depending on the sample.

\section{Results and discussion $\mathrm{pH}$ and inorganic content}

Table 1 presents the values obtained from $\mathrm{pH}$ measurements. The lowest $\mathrm{pH}$ values were observed in the Norwegian (N-187 and N-250F) and Swedish (S-383) samples, although all alum-treated samples gave lower $\mathrm{pH}$ values than that measured for sound maple ( $\mathrm{pH}$ 5.5). We are uncertain as to the reasons for the measured variability in the different objects sampled, where $\mathrm{pH}$ readings vary from $\mathrm{pH} 0-1$ to $3.5-4$. Variability may be partially related to presence of surface coatings such as linseed oil. Generally, $\mathrm{pH}$ measurement is carried out 
non-destructively using dampened $\mathrm{pH}$ strips pressed to the surface of the object. If the object is coated with linseed oil, surface $\mathrm{pH}$ readings likely do not dissolve the acidic species in the wood, but rather only alum salts concentrated on the surface. Recent experiences with reconservation of test fragments from Oseberg have shown that alum can be removed even in objects with linseed oil (not published), which supports this hypothesis. The $\mathrm{pH}$ of an alum solution lies somewhere between 3.5 and 4 , indicating that $\mathrm{pH}$ readings in this range may be due to dissolved alum salt, and not the wood. Indeed, if the inner wood is exposed through a recent break, $\mathrm{pH}$ readings from such regions can be lower than that measured on the linseed oil-coated surface. There may also be other reasons for the observed variability in $\mathrm{pH}$ readings, but we have so far not managed to determine the cause. This is discussed in greater detail in Braovac et al. [3].

Analyses by XRD and SEM-EDS were performed to characterize the inorganic components and therefore the state of the alum salt. There was not enough material for XRD analyses of the untreated Oseberg samples (N-17 and N-124). The wood components in such samples are often observable in the XRD pattern as amorphous baseline humps, as has been previously observed in XRD patterns of alum treated wood [9]. This can be seen in the XRD patterns shown in Figs. 1 and 2. In some cases, such as for N-250K in Fig. 2, a few minor peaks in the XRD pattern could not be attributed to known reference materials. We note here that XRD could only be used to identify crystalline inorganic compounds present in a high enough relative abundance that their patterns were distinguishable from those of other compounds.
The inorganic compounds unambiguously detected by XRD are summarized in Table 3. SEM-EDS confirmed the presence of the corresponding inorganic elements. In alum treatments, potassium alum (K-alum, $\left.\mathrm{KAl}\left(\mathrm{SO}_{4}\right)_{2} \cdot 12 \mathrm{H}_{2} \mathrm{O}\right)$ was usually used. However in some cases in the Oseberg collection, the use of ammonium alum $\left(\mathrm{NH}_{4}\right.$-alum, $\left.\mathrm{NH}_{4} \mathrm{Al}\left(\mathrm{SO}_{4}\right)_{2} \cdot 12 \mathrm{H}_{2} \mathrm{O}\right)$ in alum treatment mixtures has been inferred due to its presence in many objects [20], although its use was not documented at the time of treatment. The presence of K-alum as the major inorganic component in Glimmingehus, Dejbjerg and most Oseberg objects was confirmed by XRD (Figs. 1, 2) and by SEM-EDS (Fig. 3) analyses. Although the presence of ammonium alum in smaller amounts is not precluded by these results, it was only observed in object N-207 from the Oseberg collection, in which it was the major alum component [20,32]. In the PEGre-treated samples S-125h and S-346, the XRD patterns confirm that alum was removed during re-treatment.

Evidence of alum transformation was observed in the form of mercallite $\left(\mathrm{KHSO}_{4}\right)$ in the XRD patterns of samples S-383, S-383c, N-187D (Fig. 1) and N-187L. These samples were also amongst the most acidic, measuring $\mathrm{pH}$ 1.5. Mercallite has previously been identified in other Oseberg samples with a very low $\mathrm{pH}(\leq 2)$ [9]. This compound is considered to be a result of the crystallisation of the by-products of the ions formed in decomposition of alum shown in Eq. (1), i.e. crystallisation of potassium and sulfate ions in the presence of acid. As the formation of mercallite is pH dependent (pKa of $\mathrm{HSO}_{4}{ }^{-}$is ca. 2), its presence could be due to very extreme acidity in some wood samples. This acidic salt has also been observed to

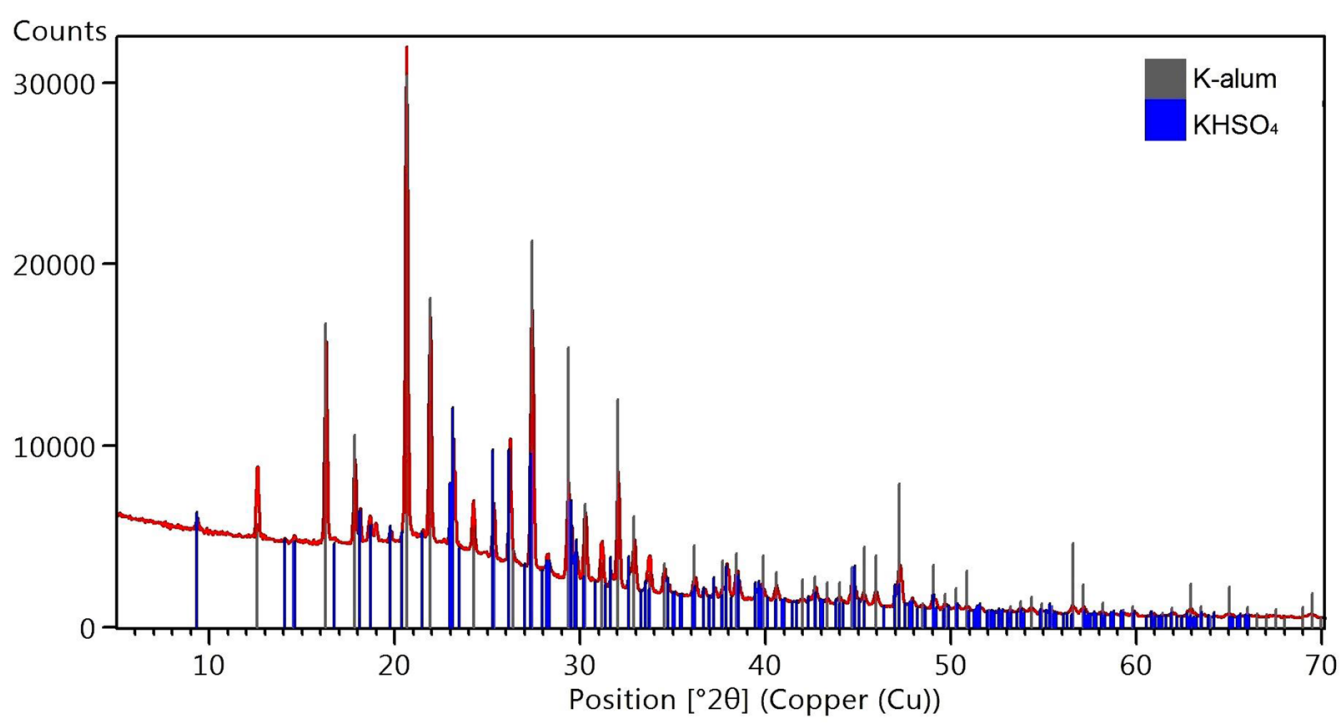

Fig. 1 X-ray diffraction pattern from sample N-187D (red), compared with $\mathrm{KHSO}_{4}$ (blue) and potassium alum (grey) references 


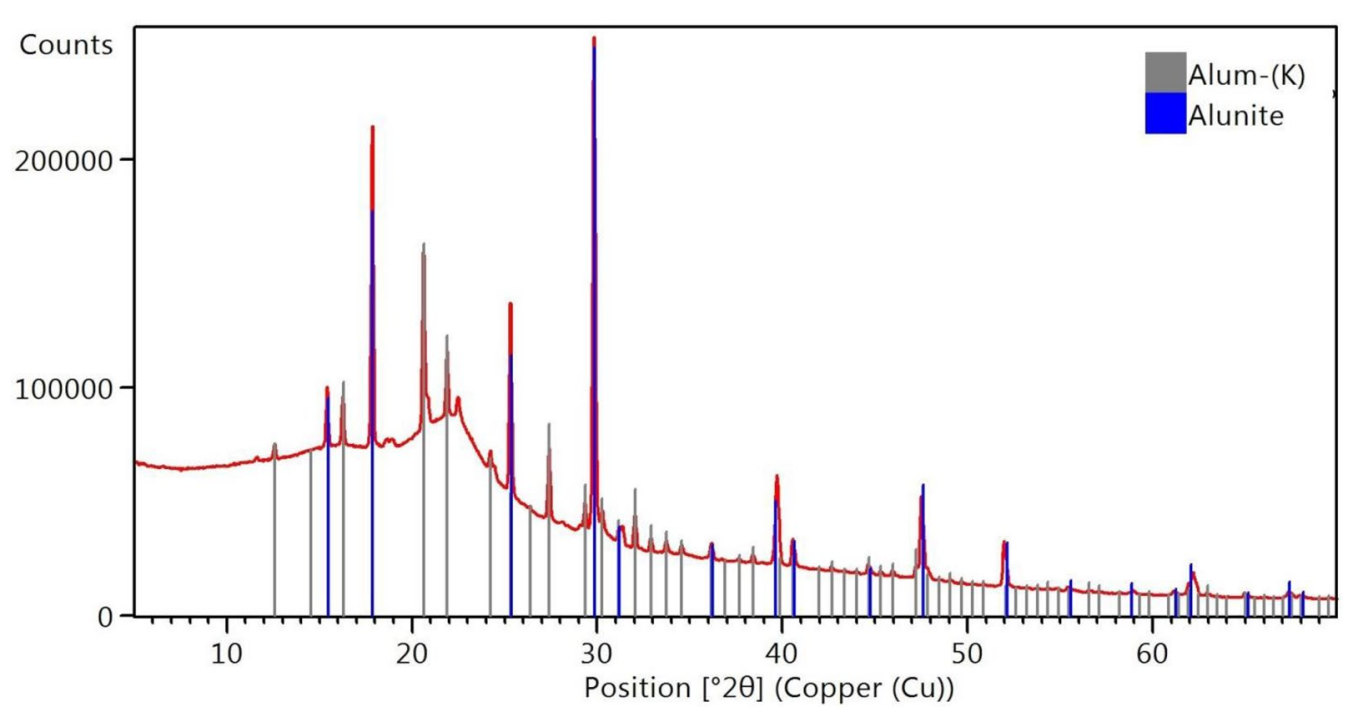

Fig. 2 X-ray diffraction pattern from sample N-250K (red) compared with alunite $\left(\mathrm{KAl}_{3}\left(\mathrm{SO}_{4}\right)_{2}(\mathrm{OH})_{6}\right.$, blue) and K-alum (grey) references

be unstable under normal museum climate conditions, which could potentially reduce the stability of alum, as it can react with it [33]. Mercallite was not detected in other samples with $\mathrm{pH} \leq 2, \mathrm{D}-\mathrm{B} 1624$ and $\mathrm{N}-250 \mathrm{~F}$. In a previous study, we noted that in the presence of other inorganic ions, such as iron, potassium and sulphate ions may preferentially form mixed sulphate compounds with these ions [34]. We have also observed in previous studies that mercallite is highly hygroscopic, unstable to temperature and humidity fluctuations, and migrates readily within wood [33]. In the case of 250F, although the sample did not contain any detectable amounts of crystalline iron compounds, the sample was taken from a small fragment that had come away from a corroding iron rod, and samples taken from other parts of this fragment contained potassium iron sulphate compounds, as observed in a previous study [34]. The lack of mercallite in this case may therefore be due to migration of potassium and sulphate ions and formation of potassium iron sulphates as a more stable crystalline product under these conditions. In the case of D-B1624, the lack of mercallite is perhaps due to its slightly higher $\mathrm{pH}$, or the presence of a certain concentration of calcium ions changing the chemical environment such that potassium and sulphate ions preferentially form syngenite with calcium instead.

Another product formed during heating of alum in solution, alunite $\left(\mathrm{KAl}_{3}\left(\mathrm{SO}_{4}\right)_{2}(\mathrm{OH})_{6}\right)$, was identified in several samples. This compound precipitates from hot aqueous alum solutions, as shown in Eq. (1), and it has also been observed previously in Oseberg artefacts [34], believed to have settled on the surface of wood fragments during treatment. The samples in which alunite was identified in the present study were all surface samples, except for N-250K (Fig. 2) and D-A1624. However, sample N-250K was taken from an area along a break, which was probably the site of a pre-existing inner crack, and we can speculate that alunite precipitated from the hot alum solution that filled the void during alum treatment. Since alunite is insoluble in water, it remained in the PEG-retreated sample S-125h even after alum removal, reflecting that it is relatively stable during re-treatment. In sample D-1624, alunite was found in the collapsed core, and likely entered from solution during the alum treatment. The apparent stability of alunite and lack of evidence of migration into the wood suggests that this material is not concerning for the state of preservation of the objects.

Some minor calcium-containing compounds were also observed in several samples from the Djebjerg and Glimmingehus collections in the form of gypsum $\left(\mathrm{CaSO}_{4} \cdot 2 \mathrm{H}_{2} \mathrm{O}\right)$ and syngenite $\left(\mathrm{K}_{2} \mathrm{Ca}\left(\mathrm{SO}_{4}\right)_{2} \cdot \mathrm{H}_{2} \mathrm{O}\right)$, supported by SEM-EDS (Fig. 3). Gypsum is a common, naturally-occurring mineral, which has also been previously observed in the Oseberg collection [34], and believed to have been deposited during burial. Syngenite presumably results from its reaction with alum or its decomposition products. The presence of gypsum and syngenite in some objects but not others is presumably related to differences in abundance of gypsum or other calcium sources in their burial environments.

\section{Analysis of organic materials}

The degradation state of wood polymers, polysaccharides and lignin, in the archaeological samples was assessed on the basis of their pyrolytic profiles obtained by Py-GC/ MS and semi-quantitative calculations. Figure 4 presents 
Table 3 Inorganic compounds detected by XRD in the samples

\begin{tabular}{|c|c|c|c|}
\hline Collection & Sample & Major compounds & $\begin{array}{l}\text { Minor } \\
\text { compounds }\end{array}$ \\
\hline \multirow[t]{8}{*}{ Dejbjerg } & D-A1624 & K-alum & Alunite, gypsum \\
\hline & D-B1624 & K-alum & Syngenite \\
\hline & D-C1628 & K-alum & Syngenite \\
\hline & D-D1626-A & K-alum & Syngenite \\
\hline & D-D1626-B & K-alum & \\
\hline & D-E1622-A & K-alum & Gypsum \\
\hline & D-E1622-B & K-alum & \\
\hline & D-F1629 & K-alum & \\
\hline \multirow[t]{6}{*}{ Oseberg } & $\mathrm{N}-187 \mathrm{D}$ & K-alum, Mercallite & \\
\hline & $\mathrm{N}-187 \mathrm{~L}$ & K-alum & Mercallite \\
\hline & N-207-A & $\mathrm{NH}_{4}$-alum & \\
\hline & N-207-B & $\mathrm{NH}_{4}$-alum & \\
\hline & $\mathrm{N}-250 \mathrm{~F}$ & K-alum & \\
\hline & $\mathrm{N}-250 \mathrm{~K}$ & K-alum, alunite & \\
\hline \multirow[t]{8}{*}{ Glimmingehus } & S-5T & K-alum & \\
\hline & $S-125 h^{a}$ & & Alunite \\
\hline & S-125k & K-alum & Alunite \\
\hline & $\mathrm{S}-346^{\mathrm{a}}$ & & \\
\hline & $S-346 d$ & K-alum, alunite & Syngenite \\
\hline & S-346e & K-alum & Alunite, syngenite \\
\hline & S-383 & K-alum & Mercallite \\
\hline & S-383c & K-alum & Mercallite \\
\hline
\end{tabular}

'Major' and 'Minor' refer to the intensity of crystalline peaks in the XRD patterns, which only reflects their relative abundance, and does not reflect the abundance of these compounds relative to the wood material or other amorphous components. 'Major' patterns showed intense, clearly defined peaks, such as those seen in Figs. 1 and 2.'Minor' patterns generally appeared as small peaks that were difficult to distinguish from the baseline, relative to the more intense 'major' pattern, but could be unambiguously identified as the assigned compound using the software and were consistent with elemental compositions observed by SEM-EDS. Chemical formulae for minerals: $\mathrm{K}$-alum $=\mathrm{KAl}\left(\mathrm{SO}_{4}\right)_{2} \cdot 12 \mathrm{H}_{2} \mathrm{O} ; \mathrm{NH}_{4}$-alum $=\mathrm{NH}_{4} \mathrm{Al}\left(\mathrm{SO}_{4}\right)_{2} \cdot 12 \mathrm{H}_{2} \mathrm{O}$; alunite $=\mathrm{KAl}_{3}\left(\mathrm{SO}_{4}\right)_{2}(\mathrm{OH})_{6} ;$ gypsum $=\mathrm{CaSO}_{4} \cdot 2 \mathrm{H}_{2} \mathrm{O}$; syngenite $=\mathrm{K}_{2} \mathrm{Ca}\left(\mathrm{SO}_{4}\right)_{2} \cdot \mathrm{H}_{2} \mathrm{O}$ mercallite $=\mathrm{KHSO}_{4}$

${ }^{\text {a }}$ Samples re-treated with PEG 2000 between 2005 and 2009

the pyrograms obtained for samples of alum treated wood from the three collections (Fig. $4 a-c$ ) and for the sample from untreated Oseberg wood fragment N-124 (Fig. 4d). In addition to the wood pyrolysis products, the organic additives applied during or after alum treatment also produced characteristic pyrolysis products which were identified [20,35] and are listed in Table 4.

\section{Organic additives: linseed oil, glycerol, polyethylene glycol} The use of linseed oil was highlighted by the presence of linear saturated fatty acids in the pyrolysis profile: myristic (tetradecanoic) acid, palmitic (hexadecanoic) acid, stearic (octadecanoic) acid and oleic ((9Z)-octadec-9-enoic) acid. The most abundant were the $\alpha, \omega$ dicarboxylic acids with respectively 8, 9 and 10 carbon atoms suberic, azelaic and sebacic acids. Of these, azelaic was the most abundant. The peak identified as glycerol in some pyrolytic profiles of the Swedish samples can derive from the use of glycerol during the original treatment. However, glycerol may also be produced by triglyceride degradation of linseed oil in the wood structure (Fig. 4b, sample N-207-A).

No organic additives were observed in the Danish samples (Fig. 4a), confirming the information received about this object from treatment reports. The pyrolytic profiles of the samples from the Dejbjerg collection showed only pyrolysis products derived from the wood polymers, lignin and holocellulose. In the Norwegian Oseberg collection linseed oil was positively identified in samples N-207-A (Fig. 4b) and N-207-B, which was in accordance with the available documentation, and in samples from fragment N-187 (N-187D, N-187L), where the use of linseed oil was not documented in treatment reports. The Swedish samples from the Glimmingehus collection, treated in 1936, were rich in linseed oil, but a very high content of glycerol was also observed (Fig. 4b). This is in line with the documents that reported the common use of glycerol in alum treatment after 1911 [5, 36]. In Swedish samples re-treated with polyethylene glycol (PEG 2000) between 2005 and 2009 (S-125h and S-346), the peaks from PEG were also identified by Py-GC/MS.

These results either confirmed the presence of additives - such as linseed oil, glycerol and PEG - which also had been documented in treatment reports or identified additives which were not originally noted in original reports. Differences between archival information and actual presence as confirmed by Py-GC/MS are indicated by an asterisk in Table 4. Identifying such compounds is important as they are now a part of the object and will have to be considered if for example reconservation will be undertaken. Such compounds may also provide insight into degradation pathways if they themselves are degraded.

\section{Wood polymers}

Semi-quantitative calculations on peak areas derived from lignin and holocellulose pyrolysis products (Table 2) were performed as described in [28]. Table 5 presents the pyrolytic composition of analysed wood samples expressed as relative percentages of holocellulose and lignin pyrolysis products.

Comparing fresh wood samples (ref. in Table 5) and archaeological untreated recently excavated (arch pine) with the untreated, naturally aged archaeological samples (head post $\mathrm{N}-124$ and finest sled pull N-17), remarkable reductions in the relative polysaccharide contents are observed. This is attributable to the anaerobic degradation of polysaccharides in the burial environment as well as to the long period these objects were stored in water 


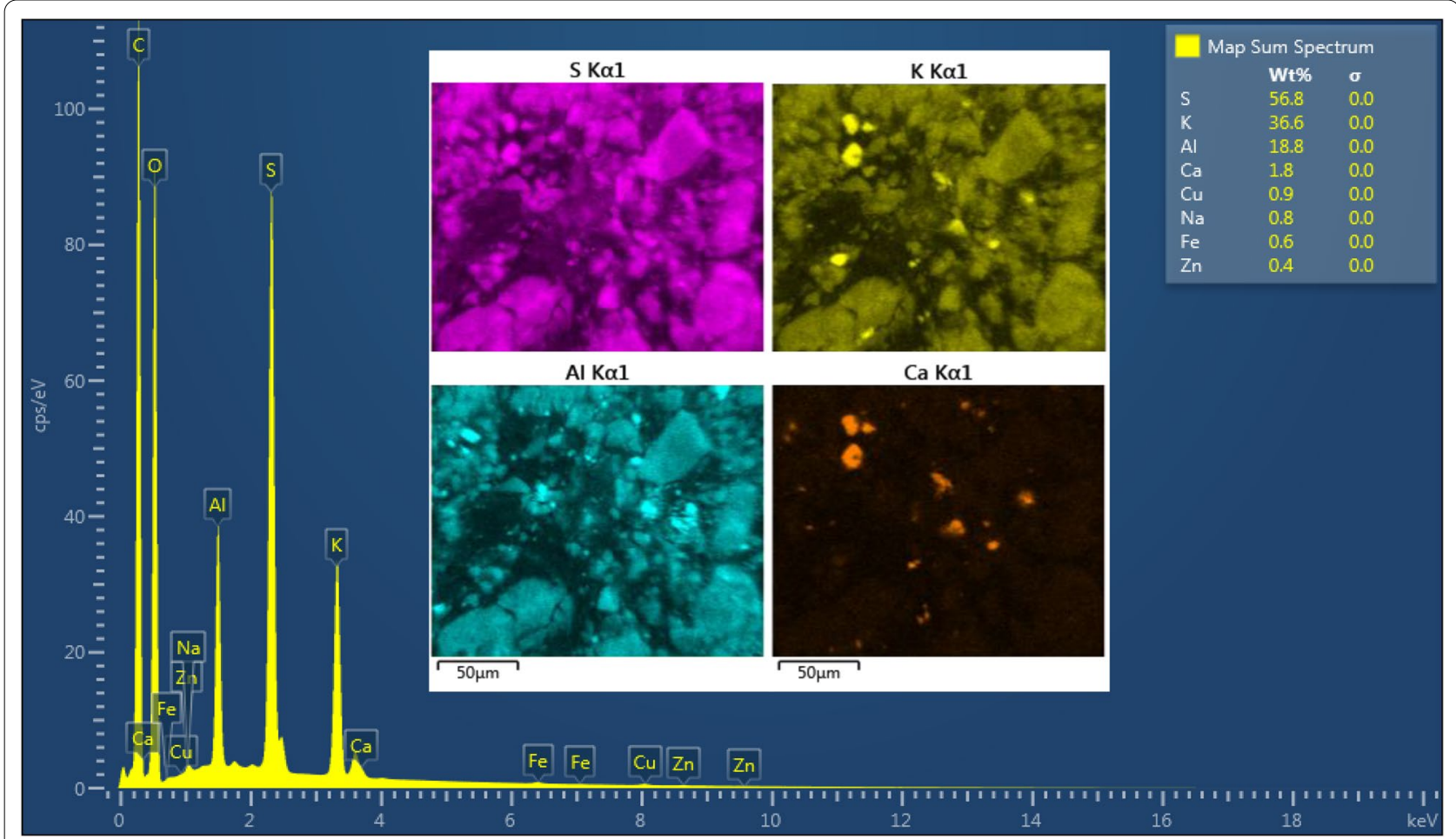

Fig. 3 SEM-EDS elemental maps of S, K, Al and Ca from sample D-C1628 showing the presence of K-alum as a major inorganic component and supporting the presence of the minor potassium calcium sulphate mineral syngenite

(ca. 35 years for $\mathrm{N}-124$ and ca. 50 years for N-17), which usually causes not only decay of the polysaccharides but also their leaching during storage in water [23]. In fact, a decrease in holocellulose content by $46 \%$ is observed for the head post (sample N-124) and by $72 \%$ for the sled pull (sample N-17) when compared to the archaeological recently excavated waterlogged wood sample (arch pine).

Almost all alum-treated wood samples showed significantly lower carbohydrate contents than fresh reference woods or recently excavated archaeological wood (arch pine), giving low values of holocellulose versus lignin ratios $(\mathrm{H} / \mathrm{L})$ (Table 5$)$. Extremely poor wood condition, with low $\mathrm{H} / \mathrm{L}$ values, was observed for almost all the samples from Danish and Norwegian collections, except for samples from fragment N-250 (N-250F, N-250K). Samples from object $\mathrm{N}-250$ appeared to be the best preserved in the Norwegian collection, with $\mathrm{H} / \mathrm{L}$ about 0.7 . Sample $\mathrm{N}-250 \mathrm{~K}$ was taken deep within the wood at a new break. Here alum was less abundant, and this region may also have absorbed less sulfate ions than surface samples. Samples from object N-187 (N-187D, N-187L), were the worst preserved in the Oseberg collection, as only traces of polysaccharides were detected, resulting in very low $\mathrm{H} / \mathrm{L}$ ratios (Table 5). In these cases, the samples mainly consisted of lignin. N-187 was very acidic ( $\mathrm{pH} 1.5)$, where mercallite $\left(\mathrm{KHSO}_{4}\right)$, an unstable acidic salt, was also identified, which may have contributed to its present degraded state.

Samples with the highest polysaccharide content belonged to the Swedish collection, which was treated most recently, in 1936, although they too showed varied relative abundances. These objects were treated with both alum and glycerol, and then coated with linseed oil. Two objects were recently retreated with PEG 2000 (S-125h, S-346). The lowest H/L ratios (lowest content of polysaccharides) in the Swedish collection were observed in samples taken from fragment 383 (S-383 and S-383c). As for the N-187 samples, this might be related to the fact that these samples were the most acidic of the Swedish collection $(\mathrm{pH}=1.5)$ and contained mercallite. As mentioned above, the reasons for variable $\mathrm{pH}$ are still uncertain.

These samples illustrate the typical variability in state of preservation in alum-treated woods previously observed in the Oseberg collection, which we tried to investigate by singling out different parameters, such as $\mathrm{pH}$ and reactive ion content contained in different samples [8]. However, we believe it involves a complexity which is difficult to relate to a single factor. We believe a combination of factors such as the original condition of the wood prior to treatment, amount of reactive metal ions absorbed by the 

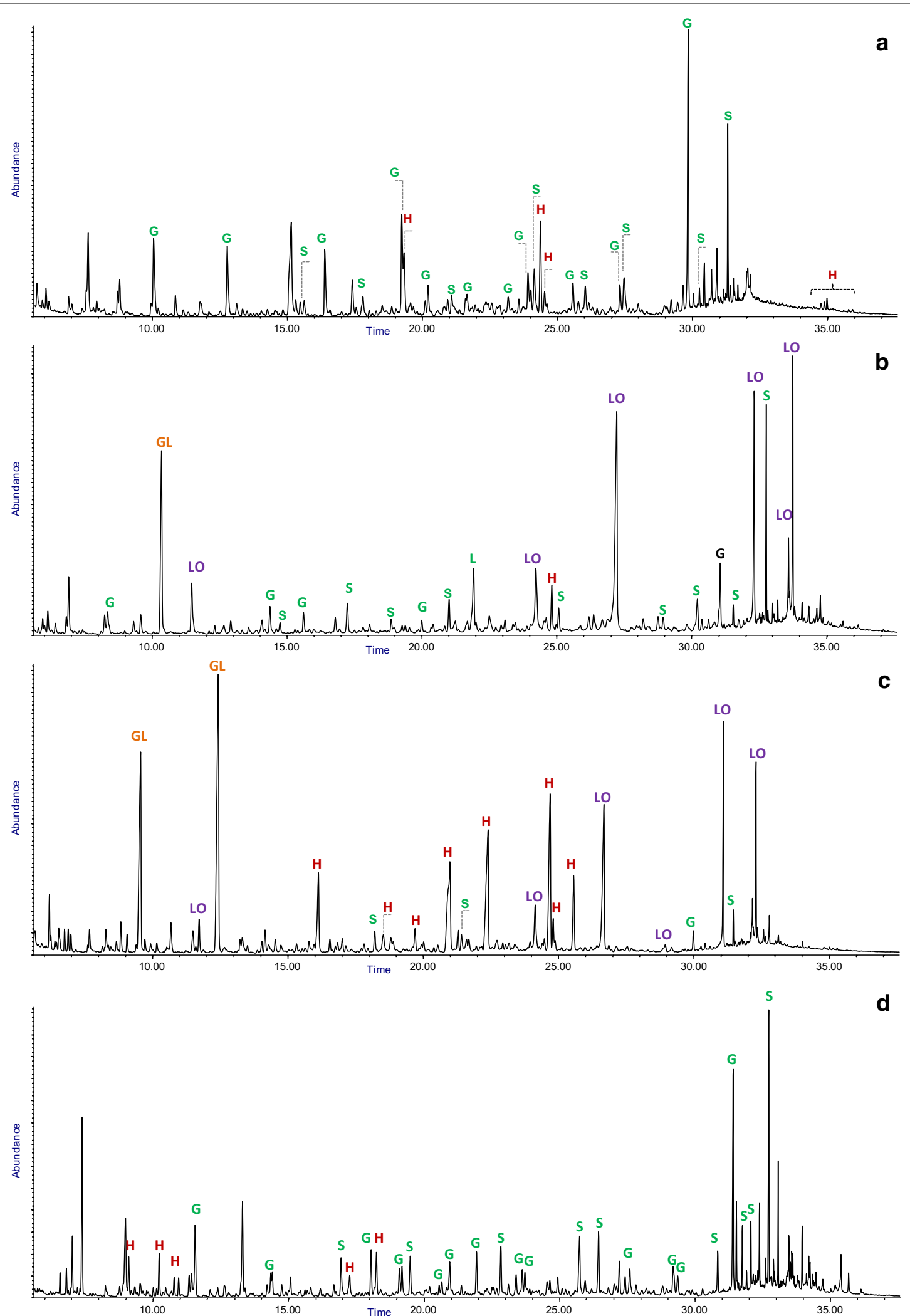

Fig. 4 Chromatographic profiles obtained by Py-GC/MS for selected samples from a the Danish Dejbjerg collection (sample D-A1624), b the Norwegian Oseberg collection (sample N-207-A), c Swedish Glimmingehus collection (sample S-125k) and d) untreated Oseberg collection (sample N-124), where: H holocellulose, L (lignin, either S or G), S (syringyl lignin) and G (G-guaiacyl), LO linseed oil, GL glycerol pyrolysis products 
Table 4 Additives used during or/and after alum treatment determined by Py-GC/MS

\begin{tabular}{|c|c|c|c|c|}
\hline Collection & Sample & Linseed oil & Glycerol & PEG \\
\hline \multirow[t]{8}{*}{ Dejbjerg } & D-A1624 & - & - & - \\
\hline & D-B1624 & - & - & - \\
\hline & D-C1628 & - & - & - \\
\hline & D-D1626-A & - & - & - \\
\hline & D-D1626-B & - & - & - \\
\hline & D-E1622-A & - & - & - \\
\hline & D-E1622-B & - & - & - \\
\hline & D-F1629 & - & - & - \\
\hline \multirow[t]{6}{*}{ Oseberg } & $\mathrm{N}-187 \mathrm{~d}$ & $+^{*}$ & - & - \\
\hline & $N-187 \mid$ & $+^{*}$ & - & - \\
\hline & $N-207 A$ & + & - & - \\
\hline & $N-207 B$ & + & - & - \\
\hline & $\mathrm{N}-250 \mathrm{~F}$ & - & - & - \\
\hline & $\mathrm{N}-250 \mathrm{~K}$ & - & - & - \\
\hline \multirow[t]{8}{*}{ Glimmingehus } & $\mathrm{S}-5 \mathrm{~T}$ & + & $+^{*}$ & - \\
\hline & $S-125 h^{a}$ & $+^{*}$ & $+^{*}$ & + \\
\hline & S-125k & $+^{*}$ & $+^{*}$ & - \\
\hline & $S-346^{a}$ & + & - & + \\
\hline & $S-346 d$ & $+^{*}$ & $+^{*}$ & - \\
\hline & S-346e & $+^{*}$ & $+^{*}$ & - \\
\hline & S-383 & + & + & - \\
\hline & S-383c & + & + & - \\
\hline
\end{tabular}

An asterisk $\left(^{*}\right)$ indicates deviation from the information obtained from treatment records, which is presented in Table 1

a Samples re-treated with PEG 2000 between 2005 and 2009. Glycerol was found in retreated S-125h likely because it was not completely washed out (some objects were packed in foam during desalination)

wood, differences in alum treatment recipes and impregnation times, wood type, and storage conditions all may play a role in determining current state of preservation of wood polymers.

Here it is necessary to add a comment on the $\mathrm{H} / \mathrm{L}$ ratio. Generally, $\mathrm{H} / \mathrm{L}$ in wood indicates the relationship between holocellulose and lignin and allows the comparison of woods of various species. When applied to archaeological wood, it usually reflects preferential relative loss of one wood component (holocellulose or lignin) with respect to the other. In the case of archaeological wood, the loss of polysaccharides usually is much greater than that of lignin. However, this index does not consider chemical changes that occur in the individual components of the wood. For this reason, information on specific chemical changes occurring in wood components can only be obtained by examining the molecular profile of the pyrolysis products of lignin and holocellulose.

\section{Chemical changes in the polysaccharide fraction of alum treated woods}

Although only found in low amounts in most of the analysed samples, the preservation state of the residual carbohydrates was assessed by examining the relative abundances of their pyrolysis products. Holocellulose pyrolysis products formed during thermal degradation were classified into five categories: cyclopentenones, furans, pyranones hydroxybenzenes and anhydrosugars, according to [37-39]. The sum of the peak areas assigned to each category (Table 2), expressed as a percentage of the total abundance of holocellulose pyrolysis products, is shown in Fig. 5a and values are shown in Additional file 1: Table S1. In reference samples from fresh woods (ref. pine, ref. maple, ref. birch), recently excavated archaeological pine wood (arch pine) and untreated naturally aged archaeological woods from the Oseberg collection (head post $\mathrm{N}-124$ and finest sled pull N-17), the main pyrolysis products of holocellulose belong to the "cyclopentenones" group [28] which is the most abundant category of holocellulose pyrolysis products.

In many of the alum-treated wood samples analysed here, we observed, as expected, higher relative abundances of anhydrosugars and a lower relative abundance of cyclopentenones relative to fresh or untreated archaeological woods, even those which were naturally aged (N-124, N-17).

Previous studies have shown that chemical alteration of polysaccharides results in a lower relative abundance of the cyclopentenones group and a higher relative abundance of anhydrosugars, compared to undegraded wood $[40,41]$.

Deviations from this trend were observed for two samples from the Swedish collection (S-125h and S-346), which had been re-treated with polyethylene glycol (PEG 2000). The first step in re-treatment with PEG involves immersing the fragments in water to remove alum salts and acidic degradation products. Thus, accumulated degradation products from polysaccharides and lignin formed after the alum treatment were presumably washed away during this process. This accounts for the differences in the relative levels of pyrolysis products from holocellulose found in these samples.

The remaining alum treated archaeological wood samples, except those from fragment N-187, showed similar polysaccharide distributions to each other, characteristic of degraded archaeological alum treated woods, with high abundances of anhydrosugars ranging from about 60\% (samples D-A1624, N-250K, S-346d, S-346e) in the better preserved samples to $80 \%$ and more for the strongly degraded ones (samples D-D1626-B, D-E1622-B, D-F1629, N-250F, S-5T, S-125k, S-383, S-383c). However, despite appearing to be the least degraded based 
Table 5 Pyrolytic composition of wooden samples expressed as a relative percentage of total pyrolysis products derived from $\mathrm{H}$-holocellulose and L-Lignin. The $\mathrm{H} / \mathrm{L}$ ratios are also shown

\begin{tabular}{|c|c|c|c|c|c|c|c|c|}
\hline \multicolumn{9}{|c|}{ Reference fresh and archaeological untreated } \\
\hline Sample & Ref. pine & Ref. maple & Ref. birch & Arch pine & Head post N-124 & Sled pull N-17 & & \\
\hline $\mathrm{H}$ & 60.7 & 59.9 & 78.5 & 49.9 & 22.9 & 35.7 & & \\
\hline L & 39.3 & 40.1 & 21.5 & 50.1 & 77.1 & 64.3 & & \\
\hline $\mathrm{H} / \mathrm{L}$ & 1.5 & 1.5 & 3.7 & 1.0 & 0.30 & 0.56 & & \\
\hline \multicolumn{9}{|c|}{ Dejbjerg, Danish } \\
\hline Sample & D-A1624 & D-B1624 & D-C1628 & D-D1626-A core & D-D1626-B surf & D-E1622-A core & D-E1622-B surf & $\begin{array}{l}\text { D- } \\
\text { F1629 }\end{array}$ \\
\hline $\mathrm{H}$ & 23.1 & 11.5 & 27.2 & 17.0 & 11.5 & 9.3 & 12.5 & 18.7 \\
\hline L & 76.9 & 88.5 & 72.8 & 83.0 & 88.5 & 90.7 & 87.5 & 81.3 \\
\hline $\mathrm{H} / \mathrm{L}$ & 0.30 & 0.13 & 0.37 & 0.21 & 0.13 & 0.10 & 0.15 & 0.23 \\
\hline \multicolumn{9}{|c|}{ Oseberg, Norwegian } \\
\hline Sample & N-187D & N-187L & N-207-A core & N-207-B surf & $\mathrm{N}-250 \mathrm{~F}$ & $\mathrm{~N}-250 \mathrm{~K}$ & & \\
\hline $\mathrm{H}$ & 2.5 & 2.0 & 8.9 & 16.9 & 43.3 & 41.0 & & \\
\hline L & 97.5 & 98.0 & 91.1 & 83.1 & 56.7 & 59.0 & & \\
\hline $\mathrm{H} / \mathrm{L}$ & 0.03 & 0.02 & 0.10 & 0.20 & 0.76 & 0.70 & & \\
\hline \multicolumn{9}{|c|}{ Glimmingehus, Swedish } \\
\hline Sample & S-5T & $\mathrm{S}-125 \mathrm{~h}$ retreated & S-125k & S-346 retreated & S-346d & S-346e & S-383 & S-383c \\
\hline $\mathrm{H}$ & 87.8 & 53.2 & 85.5 & 80.2 & 46.5 & 40.2 & 36.4 & 23.4 \\
\hline L & 12.2 & 46.8 & 14.5 & 19.8 & 53.5 & 59.8 & 63.6 & 76.6 \\
\hline $\mathrm{H} / \mathrm{L}$ & 7.2 & 1.2 & 5.9 & 4.2 & 0.9 & 0.7 & 0.6 & 0.3 \\
\hline
\end{tabular}

on $\mathrm{H} / \mathrm{L}$ ratios, the Swedish samples had the most altered polysaccharide polymers, and two of them had the highest percentage of anhydrosugars of all the analyzed samples. Samples S-5T and S-125k showed very high H/L ratios (7.2 and 5.9 respectively), which may erroneously indicate a good state of preservation of polysaccharides and a strong degradation of lignin. However, these high $\mathrm{H} / \mathrm{L}$ ratios are rather due to the very high percentages of anhydrosugars in these samples $(89.8 \%$ and $90.8 \%$, respectively), which indicate strong depolymerisation of the holocellulose fraction. It is unclear why these two samples had such high relative abundances of anhydrosugars, but as mentioned above, it may be related to several factors about which we do not have information.

\section{Chemical changes in the lignin polymer}

Chemical changes in the lignin polymer were evaluated from the lignin pyrolysis product distribution profiles, shown in Fig. 5b, categorised as monomers, short chain, long chain, demethylated and oxidised (Table 2). Differences between archaeological alum-treated woods and references from both fresh (ref. pine, maple and birch) and untreated recently excavated archaeological pine wood were observed to a certain degree, indicating alterations in the lignin polymer caused by alum treatment. The lignin profiles for the untreated archaeological woods from the Oseberg collection (N-124, N-17) differ from the recently excavated archaeological wood (arch pine), mainly in oxidized pyrolysis products, most likely due to the natural aging of these fragments.

Generally, waterlogged archaeological wood mainly undergoes polysaccharide decay by erosion bacteria in anaerobic environments. The lignin polymer in untreated archaeological waterlogged wood remains almost unaltered (arch pine, Fig. 5b, Additional file 1: Table S2), with only some minor changes [28] compared to undegraded fresh wood. The chemical differences observed between the recently excavated pine wood and the alum-treated archaeological wood samples indicate that a different decay process has likely occurred in the alum treated woods, based on acid hydrolysis and oxidation.

The most evident degradation process observed in the alum-treated wood samples is oxidation of the lignin, which is highlighted by the high relative abundance of lignin pyrolysis products with carbonyl and carboxyl moieties (the 'oxidized' group was calculated as the sum of pyrolysis products with carbonyl and carboxyl functionalities, (Fig. 5b, Additional file 1: Table S2) [20, 
a

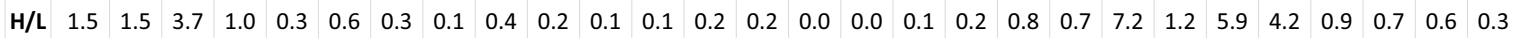

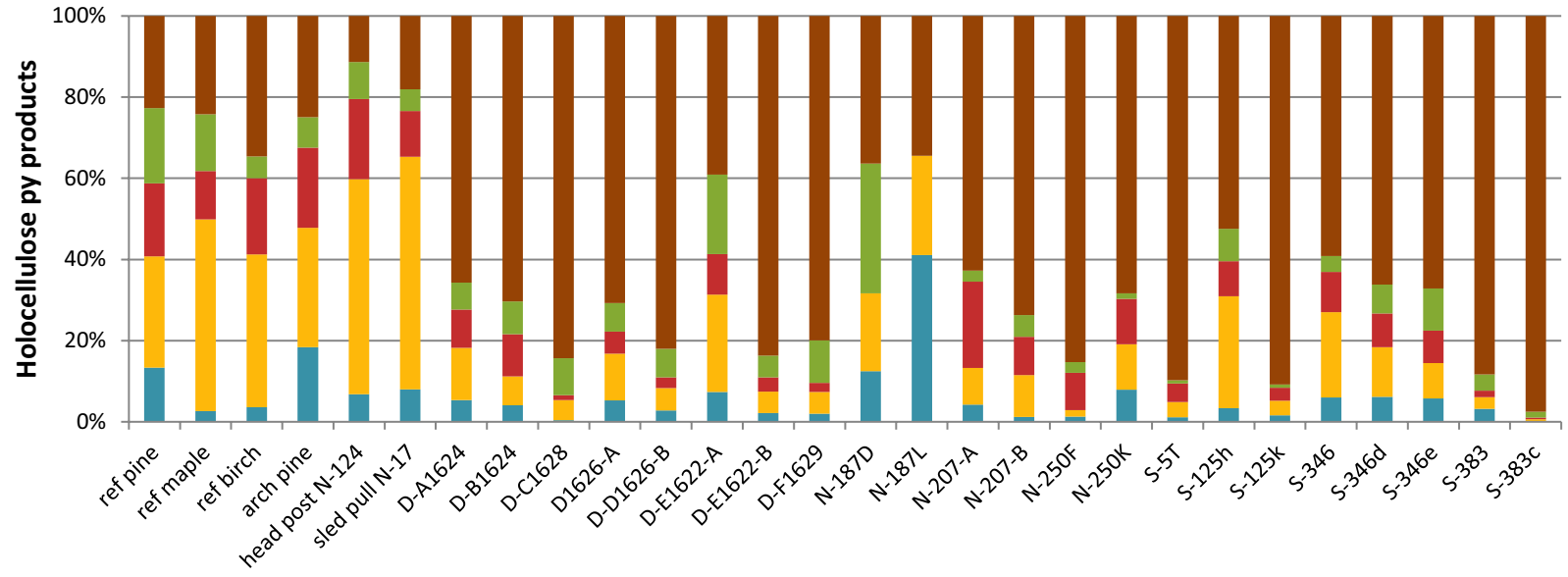

b

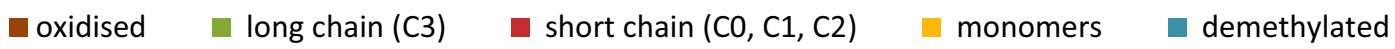

\begin{tabular}{lllllllllllllllllllll|l|l|l|l|l|l|l|l|l} 
H/L & 1.5 & 1.5 & 3.7 & 1.0 & 0.3 & 0.6 & 0.3 & 0.1 & 0.4 & 0.2 & 0.1 & 0.1 & 0.2 & 0.2 & 0.0 & 0.0 & 0.1 & 0.2 & 0.8 & 0.7 & 7.2 & 1.2 & 5.9 & 4.2 & 0.9 & 0.7 & 0.6 & 0.3
\end{tabular}

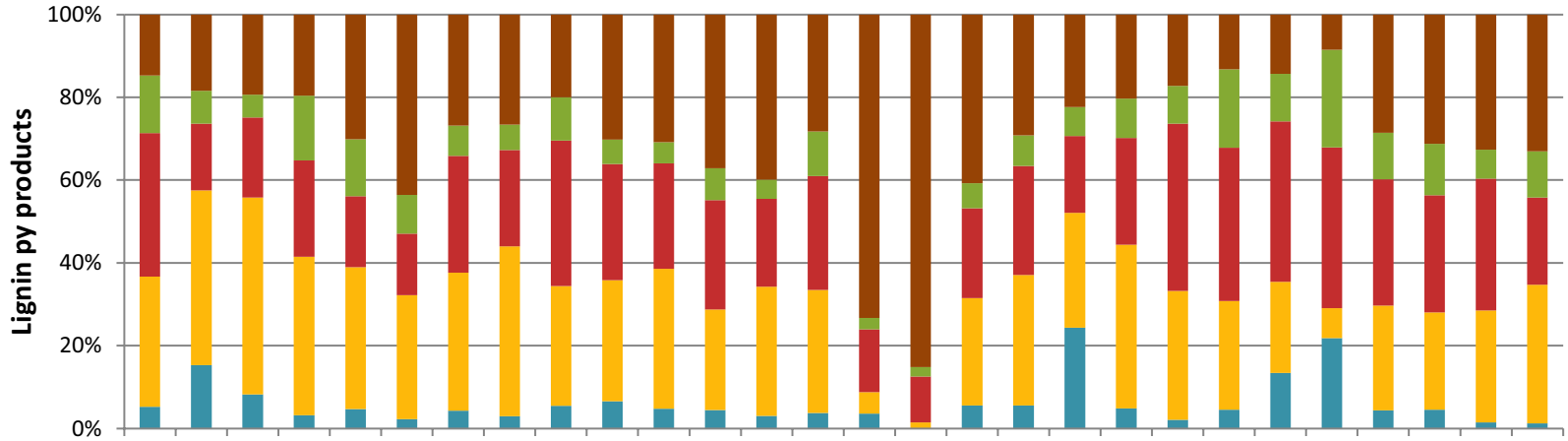

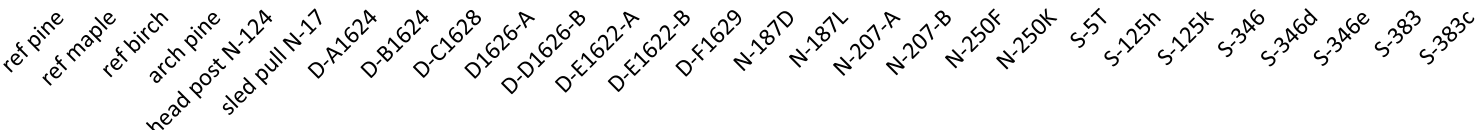

Fig. 5 Percentage distribution of a holocellulose and $\mathbf{b}$ lignin pyrolysis product categories in each sample; where the prefix D—Danish Dejbjerg, $\mathrm{N}$-Norwegian Oseberg and S-Swedish Glimmingehus collection

$25,42]$. Such abundance of lignin oxidation products is uncommon in archaeological wood from anaerobic environments as shown in the archaeological pine sample (arch pine). As mentioned above, the high abundance of oxidised pyrolysis products in the untreated archaeological wood samples from the Oseberg collection N-124 and $\mathrm{N}-17$ relative to the other untreated woods is likely attributable to natural aging since their excavation in 1904. In these samples, most of the oxidized products have carbonyl functionalities rather than carboxyl, whereas lignin pyrolysis products with carboxyl groups dominate the oxidized fraction in alum-treated woods from Oseberg (Additional file 1: Table S2).
Some alum treated wood samples present high or very high abundances of products with carbonyl and carboxyl functionalities (Additional file 1: Table S2), indicating lignin oxidation. In particular, Norwegian alum treated $\mathrm{N}-187 \mathrm{D}$ and $\mathrm{N}-187 \mathrm{~L}$, had highest relative amounts of oxidised lignin pyrolysis products of all samples. The majority of the samples from the Swedish collection (S-5T, S-125h, S-125k, S-346) contained low abundances of carbonyl and acidic pyrolysis products. The low abundances of oxidized lignin pyrolysis products in samples S-125h and S-346 may be due to their recent retreatment with PEG where degradation products from both polysaccharides and lignin were likely leached out during 
immersion in water. As for samples S-5T, S-125k, both collected from the outer part of the wooden objects, the low oxidation level of lignin may be due to the presence of linseed oil, which may undergo preferential oxidation, effectively reducing the oxidative degradation of lignin, as was observed in previous analyses of samples from the same object as $\mathrm{N}-207$, where oxidation at the linseed-oilrich surface was lower than in regions with less linseed oil deeper inside the wood [20]. Although N-187 also had linseed oil, there was very little and may be one of the reasons the degradation was greater in this sample.

The monomer group is the most abundant category in reference woods (between 31 and $48 \%$ for sound woods and about $38 \%$ for recently excavated archaeological pine (arch pine) as well as in many of the alum-treated wood samples, except for N-187 and S-346 (retreated) (Fig. 5b, Additional file 1: Table S2) which showed very low relative abundances of monomers. Lower abundances of monomers indicate that structural changes have occurred in the lignin polymer. In the case of S-346, some watersoluble lignin fragments may have leached out during retreatment, indicating a precarious lignin structure already before re-treatment. The same phenomenon was observed during classical wet analysis, which consist in the determination of the quantity of wood components (holocellulose, cellulose, lignin) by isolating, purifying, and quantifying the wood constituents by weight $[29,43]$, for example using TAPPI methods $[44,45]$ and chlorite methods proposed by Wise et al. [46] applied to waterlogged wood [47].

Most of the alum treated samples had higher relative abundances of "short chain" pyrolysis products compared to untreated ones (arch pine, $\mathrm{N}-124$ and $\mathrm{N}-17$ ), again pointing to alteration of the lignin polymer (depolymerisation) in almost all alum treated woods. A different trend is observed in sample S-346 (retreated), where degradation products of lower molecular weight are likely removed during retreatment. Also, samples N-187L and N-187D present a different profile. These woods have much higher relative abundances of "carboxyl" lignin pyrolysis products (Additional file 1: Table S2), indicating extreme depolymerization.

Demethylation is known to occur in degradation pathways initiated by fungi or bacteria. This phenomenon was only seen in a few analysed samples, where high relative abundances of demethylated pyrolysis products were observed. In sound woods, demethylated pyrolysis products range from 5 to $15 \%$ of total lignin. Samples N-250F (Oseberg collection) and S-346 (Glimmingehus collection) contained between 21 and $24 \%$ demethylated lignin pyrolysis products, relative to total lignin. The other alum treated wood samples showed markedly lower contents of demethylated units (ca. 5\% of total lignin content), similar to those found in untreated archaeological woods (N-124 and N-17). Demethylation results in lignin units with hydroxyl groups which are more reactive, and thus susceptible to further reactions, as discussed by van Bergen et al. [48]. This may explain the lower content of demethylated products in samples which show greater lignin degradation than in N-250F, based on carboxyllignin relative abundance. However, the lignin in N-250K, which has low amounts of demethylated units compared to $\mathrm{N}-250 \mathrm{~F}$, also has low relative abundances of carboxyl units, indicating a better state of preservation than in $\mathrm{N}-250 \mathrm{~F}$. The better state of preservation of $\mathrm{N}-250 \mathrm{~K}$ could be due to the fact that it was taken deep within the wood at a new break, where alum was less abundant than in other samples, as noted above. It is also possible that iron ions, which were not quantified in this study, may play a role in demethylation rate. $\mathrm{N}-250 \mathrm{~F}$ was taken from a fragment which contained an iron rod. Although no iron compounds were detected in this sample, it is very likely that small amounts of iron are present, which may affect the local wood chemistry differently than in N-250K. In the case of S-346, which was recently retreated, the high demethylation may indicate that lignin here is still actively degrading, even after retreatment, for reasons which will require further work.

\section{Conclusions}

A multi-analytical approach was applied to study wooden archaeological artefacts from three different Scandinavian collections that had been treated with alum at different points in time. The objects from the Danish collection, Dejbjerg, were treated the earliest, in 1883. Next was the Oseberg collection which was treated between 1905 and 1913. The Glimmingehus artefacts were treated with alum in 1936. Both the Norwegian and Swedish collections had additional compounds applied either during (glycerol) or after treatment (linseed oil). Both linseed oil and glycerol were contained in all the Glimmingehus samples. The presence of linseed oil was observed by Py-GC/MS in both N-187 and N-207 fragments. Linseed oil may reduce oxidation of wood saturated with it. In the case of N-187, the linseed oil was not detectable visually, only by Py-GC/MS, so it may not have offered protection. The presence of additives is important to confirm by analysis, as the original treatment records are not always accurate. This is important because additives may influence state of preservation (as with linseed oil) or it may interfere with a planned retreatment.

All alum-containing samples were found to have been treated with mostly K-alum, except for the N-207 samples, which were shown to have been treated with primarily ammonium alum. Treatment records did not indicate that the Oseberg collection was treated with 
ammonium alum. Both $\mathrm{K}$-alum and $\mathrm{NH}_{4}$-alum have similar physical properties, and older sources mention that $\mathrm{K}$-alum was often sold mixed with $\mathrm{NH}_{4}$-alum. We tried to see whether the type of alum affected state of preservation, which could partially explain the observed variability of preservation of the Oseberg collection but we could not find differences [32].

Surface $\mathrm{pH}$ measurements revealed very acidic values of 1.5-2.5 in many of the analysed objects, in some cases 3.0-3.5. We have had difficulty linking state of degradation to $\mathrm{pH}$. However, in cases where the unstable acidic salt mercallite $\left(\mathrm{KHSO}_{4}\right)$ was also identified as a product of alum decomposition in samples with $\mathrm{pH} 1.5$ (N-187D, $\mathrm{N}-187 \mathrm{~L}, \mathrm{~S}-383, \mathrm{~S}-383 \mathrm{c}$ ), presumably formed from excess absorbed sulfates, as a result of very extreme acidity. In such cases, there may have been lack of cations which bind with acidic sulfates (such as $\mathrm{Ca}$ ) which may remove it from further reactions through the formation of other salts, such as syngenite. Another material resulting from the alum treatment is alunite $\left(\mathrm{KAl}_{3}\left(\mathrm{SO}_{4}\right)_{2}(\mathrm{OH})_{6}\right)$, which precipitates from hot alum solutions during treatment and therefore was often found only on samples taken from outer parts of objects. Alunite was still present even after re-treatment with PEG 2000. Minor calcium compounds were also observed in several samples by XRD and SEM-EDS, presumably having been deposited during burial and, in some cases, formed through reactions with alum and/or its decomposition products.

Analytical pyrolysis allowed not only to identify the organic conservation materials used during and after the alum treatment, but also provided an evaluation of the state of degradation of the archaeological alum treated woods. The wooden objects belonging to the Norwegian (Oseberg) and Danish (Dejbjerg) collections, were the most degraded in terms of polysaccharides (i.e. very low $\mathrm{H} / \mathrm{L}$ ratios). On the other hand, polysaccharides were still present but mostly degraded and depolymerized in the the Swedish (Glimmingehus collection) samples. Although they showed fairly high $\mathrm{H} / \mathrm{L}$ ratios, the very high percentage of anhydrosugars observed demonstrates a strong depolymerisation of the holocellulose fraction.

The Glimmingehus collection was treated later than the collections from Denmark and Norway, however degradation appeared to be influenced not only by age, but also by the storage conditions and by the presence of additives such as glycerol, which is highly hygroscopic and could have increased the moisture uptake of the Glimmingehus samples. Increased humidity can cause an increase in the catalytic activity of the acidic compounds [49] present in the wood and cause further decay. The presence of linseed oil, however, can play a protective role in the alum treated woods [20]. In fact, most fragments containing linseed oil on their surfaces appeared better preserved than those without, with the exception of $\mathrm{N}-187$ samples.

Regarding the lignin fraction, the fragment N-187 from the Oseberg collection (Norwegian) appeared to be strongly oxidized, with very high relative abundances of carboxyl functionalities.

High levels of lignin oxidation were however also found in some samples from the Danish and Swedish collections, but here oxidized lignin was mainly found as carbonyl functionalities. Thus, oxidation of lignin is not always caused by the alum treatment, but it can also be due to other factors such as the burial environment, natural aging after recovery (as illustrated in N-124 and $\mathrm{N}-17$ ), or initial preservation condition (which is an unknown here), as well as the presence of surface treatments (like linseed oil).

Alum treatment may cause also lignin depolymerization as illustrated by the high percentage of short chain lignin pyrolysis products.

In the samples from Glimmingehus (Sweden) that were re-treated with PEG between 2005 and 2009, the pyrolysis product profiles for both holocellulose and lignin fractions differed from those from the same object that had not been re-treated. This is likely due to a partial leaching of the degradation products formed since the alum treatment in the 1930s, which occurred in the desalination phase of the retreatment.

This study highlights that the time elapsed since the conservation treatment with alum can play an important role in the extent of degradation observed today: the objects treated earlier in time were found to be in a worse condition than those treated later on, as in the case of Danish Dejbjerg and Norwegian Oseberg collections. However, the analysis of the more recently treated samples from Sweden showed that time is not the only factor involved in defining the extent of degradation. Here, we observed that objects containing glycerol were in a very poor condition, shown by their high levels of depolymerisation of both holocellulose and lignin. Therefore, in addition to the number of years since the alum-treatment, other factors which can potentially influence the extent of degradation observed today include the original condition of the wood prior to treatment, differences in alum treatment recipes and impregnation times, wood type, and storage conditions.

\section{Abbreviations}

Alum: Aluminium potassium sulphate; Alunite: $\mathrm{KAl}_{3}\left(\mathrm{SO}_{4}\right)_{2}(\mathrm{OH})_{6} ; \mathrm{AMDIS}$ : Automated Mass Spectral Deconvolution and Identification System; Gypsum: $\mathrm{CaSO}_{4} \cdot 2 \mathrm{H}_{2} \mathrm{O} ; \mathrm{H} / \mathrm{L}$ : Values of holocellulose versus lignin ratio; $\mathrm{K}$-alum: $\mathrm{KAl}\left(\mathrm{SO}_{4}\right)_{2} \cdot 12 \mathrm{H}_{2} \mathrm{O}$; Mercallite: $\mathrm{KHSO}_{4}$; $\mathrm{NH} 4$-alum: $\mathrm{NH}_{4} \mathrm{Al}\left(\mathrm{SO}_{4}\right)_{2} \cdot 12 \mathrm{H}_{2} \mathrm{O}$; $\mathrm{PEG} 2000$ : Polyethylene glycol 2000 with Molar Mass 1800.00 g/mol; Py-GC/MS: Analytical pyrolysis coupled with gas chromatography and mass spectrometry; 
SEM-EDS: Scanning electron microscopy with energy-dispersive $X$-ray spectroscopy; Syngenite: $\mathrm{K}_{2} \mathrm{Ca}\left(\mathrm{SO}_{4}\right)_{2} \cdot \mathrm{H}_{2} \mathrm{O} ; \mathrm{XRD}$ : X-ray diffraction.

\section{Supplementary Information}

The online version contains supplementary material available at https://doi. org/10.1186/s40494-021-00517-0.

Additional file 1: Table S1. Relative abundance of categorized holocellulose pyrolysis products as a \% of total holocellulose. Table S2. Relative abundance of categorized lignin pyrolysis products as a \% of total lignin.

Additional file 2: Figure S1. N-124 (Oseberg collection) reference sample was taken from a destroyed animal head post from a region that was unaffected by other compounds. Figure S2. N-207-A was taken from the core and N-207-B was taken from the surface (Oseberg collection). Arrows point to approximate sampling locations. Figure S3. N-187 (Oseberg collection), taken from lighter (I) and darker (d) parts of the same object. Figure S4. N-250 (Oseberg collection): Samples from these regions did not contain linseed oil since they were taken below the surface. The light areas on the $\mathrm{X}$-ray image show the uneven distribution of the alum salts in the object. Figure S5. S-125h (Glimmingehus collection), surface sample. This object was reconserved with PEG 2000 in 2009. The scalpel indicates sampling site. Figure S6. S-346 surface sample (Glimmingehus collection) . This object was reconserved with PEG 2000 in 2009. The lower tweezer tine indicates sampling site. Figure S7. S-125k surface sample (Glimmingehus collection). The scalpel indicates sampling site. Figure S8. S-5T sampled from a loose sliver from the surface (Glimmingehus collection). Figure S9. S-346d surface sample (Glimmingehus collection). The scalpel indicates sampling site. Figure S10. S-346e surface sample (Glimmingehus collection). The scalpel indicates sampling site. Figure S11. S-383 surface sample (Glimmingehus collection). The scalpel indicates sampling site. Figure S12. S-383c surface sample (Glimmingehus collection). The scalpel indicates sampling site. Figure S13. D-A1624 (Dejbjerg collection) core sample. The scalpel indicates sampling site. Figure S14. D-B1624 (Dejbjerg collection) surface sample. The scalpel indicates sampling site. The treatment record is also shown. Figure S15. D-C1628 (Dejbjerg collection) surface sample. The scalpel indicates sampling site. Figure S16. D-D1626-A core and D-D1626-B (below) surface samples (Dejbjerg collection). The pins indicate sampling sites. Also shown is an magnified image of the collapsed wood structure. Figure S17. D-E1622-A core (right) and D-E1622-B (below) surface (left) samples (Dejbjerg collection). The scalpel indicates sampling sites. Figure S18. D-F1629 (Dejbjerg collection) surface sample. The scalpel indicates sampling site. Photo credits: Museum of Cultural History, University of Oslo.

\section{Acknowledgements}

We wish to thank Kristiane Strætkvern from the National Museum of Denmark and Lovisa Dal and Jenny Bergman from the Historical Museum at Lund University, for facilitating the sampling of objects by SB and MS.

\section{Authors' contributions}

JJL methodology, investigation, data interpretation, writing- original draft preparation, review and editing; CM methodology, investigation, data interpretation, writing — review and editing; MS conceptualization, methodology, investigation, writing — review and editing; FM data interpretation, writingreviewing and editing; MPC reviewing and editing; SB conceptualization, methodology, investigation, supervision, review and editing. All authors read and approved the final manuscript.

\section{Funding}

This research was carried out within the Saving Oseberg project, funded by the Norwegian Ministry of Education and Research and the University of Oslo. Py-GC/MS analysis were partially funded by the University of Pisa project "Advanced analytical pyrolysis to study polymers in renewable energy, environment, cultural heritage" (PRA_2018_26, 2018-2020).

\section{Availability of data and materials}

The datasets used and/or analysed during the current study are available from the corresponding author on reasonable request.

\section{Declarations}

\section{Competing interests}

The authors declare that they have no competing interests.

\section{Author details}

${ }^{1}$ Department of Chemistry and Industrial Chemistry, University of Pisa, via Moruzzi 13, 56124 Pisa, Italy. ${ }^{2}$ Department of Collection Management, Museum of Cultural History, University of Oslo, Oslo, Norway. ${ }^{3}$ Swedish National Maritime Museums, Stockholm, Sweden.

Received: 21 December 2020 Accepted: 1 April 2021

Published online: 03 June 2021

\section{References}

1. Speerschneider CA. Behandling af oldsager af træ, som ere fundne i moser for at bevare dem i deres oprindelige form og farve. Antiquarisk Tidsskrift. Kjøbenhavn: Det kongelige nordiske oldskrift-selskab; 1861. p. $176-178$.

2. Herbst CF. Om bevaring af oldsager af træ fundne i törvemoser. Antiquarisk tidsskrift. Kjøbenhavn: Det kongelige nordiske oldskrift-selskab; 1861. p. 174-176.

3. Braovac S, McQueen CMA, Sahlstedt M, Kutzke H, Łucejko JJ, Klokkernes T. Navigating conservation strategies: linking material research on alumtreated wood from the Oseberg collection to conservation decisions. Herit Sci. 2018;6(1):77.

4. Brøgger AW, Shetelig H, Falk H. Osebergfundet. Oslo: Distribuert ved Universitetets Oldsaksamling; 1917.

5. Brorson Christensen B. The conservation of waterlogged wood in the National Museum of Denmark: with a report on the methods chosen for the stabilization of the timbers of the viking ships from Roskilde Fjord, and a report on experiments carried out in order to improve upon these methods. Copenhagen: The National Museum of Denmark; 1970.

6. Mortensen MN, Chaumat G, Gambineri F, Kutzke H, Łucejko JJ, McQueen CMA, et al. Climatically induced degradation processes in conserved archaeological wood studied by time-lapse photography. Stud Conserv. 2019;64(2):115-23.

7. Bojesen-Koefoed IM, Stief M, Nørlem SJ. New conservation and display. In: Crumlin-Pedersen O, Trakadas A, editors. Hjortspring: a pre-roman Ironage warship in context. Roskilde: Viking Ship Museum in Roskilde; 2003. p. 44-53.

8. Braovac S, Tamburini D, Łucejko JJ, McQueen C, Kutzke H, Colombini MP. Chemical analyses of extremely degraded wood using analytical pyrolysis and inductively coupled plasma atomic emission spectroscopy. Microchem J. 2016;124:368-79.

9. McQueen CMA, Tamburini D, Łucejko JJ, Braovac S, Gambineri F, Modugno F, et al. New insights into the degradation processes and influence of the conservation treatment in alum-treated wood from the Oseberg collection. Microchem J. 2017;132:119-29.

10. Braovac $\mathrm{S}$, Kutzke $H$. The presence of sulfuric acid in alum-conserved wood_origin and consequences. J Cult Herit. 2012;13(3):S203-8.

11. Qi W, Zhang S, Xu Q, Li H, Ren Z, Li T, et al. Model for continual depolymerization of biomass catalyzed by dilute sulfuric acid. Chem Eng Technol. 2009;32(4):534-40.

12. Wang C, Zhang L, Zhou T, Chen J, Xu F. Synergy of Lewis and Brønsted acids on catalytic hydrothermal decomposition of carbohydrates and corncob acid hydrolysis residues to 5-hydroxymethylfurfural. Sci Rep. 2017;7:40908-40908.

13. Zhou L, Zou H, Nan J, Wu L, Yang X, Su Y, et al. Conversion of carbohydrate biomass to methyl levulinate with $\mathrm{Al}_{2}\left(\mathrm{SO}_{4}\right)_{3}$ as a simple, cheap and efficient catalyst. Catal Commun. 2014;50:13-6.

14. Brazdausks P, Paze A, Rizhikovs J, Puke M, Meile K, Vedernikovs N, et al. Effect of aluminium sulphate-catalysed hydrolysis process on furfural yield and cellulose degradation of Cannabis sativa L. shives. Biomass Bioenergy. 2016;89:98-104.

15. Nguyen QA, Tucker MP. Dilute acid/metal salt hydrolysis of lignocellulosics. Mildwest Research Institute: Kansas City; 2002. p. 8. 
16. Gupta D, Ahmad E, Pant KK, Saha B. Efficient utilization of potash alum as a green catalyst for production of furfural, 5-hydroxymethylfurfural and levulinic acid from mono-sugars. RSC Adv. 2017;7(67):41973-9.

17. Chamberlain D. Anion mediation of aluminium-catalysed degradation of paper. Polym Degrad Stab. 2007;92(7):1417-20.

18. Baty J, Minter W, Lee S. The role of electrophilic metal ions aluminum (III) and magnesium (II) in paper degradation and deacidification, American Institute for the Conservation of Historic and Artistic Works. In: 38th Annual Meeting. Milwaukee, Wl; 2010.

19. Baty J, Sinnott ML. Efficient electrophilic catalysis of 1,5-anhydrocellobiitol hydrolysis by AI III; implications for the conservation of "rosin-alum" sized paper. Chem Commun. 2004;7:866-7.

20. Łucejko JJ, La Nasa J, McQueen CMA, Braovac S, Colombini MP, Modugno F. Protective effect of linseed oil varnish on archaeological wood treated with alum. Microchem J. 2018;139:50-61

21. Rosenqvist AM. The stabilizing of wood found in the viking ship of Oseberg: part I. Stud Conserv. 1959;4(1):13-22

22. Rosenqvist $A M$. The stabilizing of wood found in the viking ship of Oseberg: part II. Stud Conserv. 1959;4(2):62-72.

23. Pedersen NB, Łucejko JJ, Modugno F, Björdal C. Correlation between bacterial decay and chemical changes in waterlogged archaeological wood analysed by light microscopy and Py-GC/MS. Holzforschung. 2020. https://doi.org/10.1515/hf-2020-0153.

24. Tamburini D, Łucejko JJ, Zborowska M, Modugno F, Cantisani E, Mamoňová M, et al. The short-term degradation of cellulosic pulp in lake water and peat soil: a multi-analytical study from the micro to the molecular level. Int Biodeterior Biodegrad. 2017:116:243-59.

25. Tamburini D, Łucejko JJ, Ribechini E, Colombini MP. New markers of natural and anthropogenic chemical alteration of archaeological lignin revealed by in situ pyrolysis/silylation-gas chromatography-mass spectrometry. J Anal Appl Pyrol. 2016;118:249-58.

26. Mattonai M, Tamburini D, Colombini MP, Ribechini E. Timing in analytical pyrolysis: Py(HMDS)-GC/MS of glucose and cellulose using online micro reaction sampler. Anal Chem. 2016;88(18):9318-25.

27. Smits MM, Carleer R, Colpaert JV. PYQUAN: a rapid workflow around the AMDIS deconvolution software for high throughput analysis of pyrolysis GC/MS data. J Anal Appl Pyrol. 2016;118:335-42.

28. Tamburini D, Łucejko JJ, Zborowska M, Modugno F, Prądzyński W, Colombini MP. Archaeological wood degradation at the site of Biskupin (Poland): wet chemical analysis and evaluation of specific Py-GC/MS profiles. J Anal Appl Pyrol. 2015;115:7-15.

29. Łucejko JJ, Zborowska M, Modugno F, Colombini MP, Pradzynski W. Analytical pyrolysis vs. classical wet chemical analysis to assess the decay of archaeological waterlogged wood. Anal Chim Acta. 2012;745:70-7.

30. Tamburini D, Łucejko JJ, Modugno F, Colombini MP. Characterisation of archaeological waterlogged wood from Herculaneum by pyrolysis and mass spectrometry. Int Biodeterior Biodegrad. 2014;86(Part B):142-9.

31. Degen T, Sadki M, Bron E, König U, Nénert G. The HighScore suite. Powder Diffr. 2014;29(S2):S13-8.

32. McQueen CMA, Łucejko JJ, Flåte IMT, Modugno F, Braovac S. Ammonium alum in alum-treated wooden artefacts: discovery, origins and consequences. Herit Sci. 2019;7(1):78.

33. McQueen CMA, Steindal CC, Narygina O, Braovac S. Temperature- and humidity-induced changes in alum-treated wood: a qualitative X-ray diffraction study. Herit Sci. 2018;6(1):66.

34. McQueen CMA, Tamburini D, Braovac S. Identification of inorganic compounds in composite alum-treated wooden artefacts from the Oseberg collection. Sci Rep. 2018;8(1):2901.
35. Tamburini D, Łucejko JJ, Modugno F, Colombini MP. Combined pyrolysisbased techniques to evaluate the state of preservation of archaeological wood in the presence of consolidating agents. J Anal Appl Pyrol. 2016;112:429-41

36. Rosenberg GA. The preservation of antiquities of organic material. Museums J. 1934;33:432-7

37. Moldoveanu SC. Analytical pyrolysis of polymeric carbohydrates. In: Coleman D, Price BF, editors. Analytical pyrolysis of natural organic polymers. Amsterdam: Elsevier Science; 1998. p. 217-316.

38. Pouwels AD, Eijkel GB, Boon JJ. Curie-point pyrolysis-capillary gas chromatography-high-resolution mass spectrometry of microcrystalline cellulose. J Anal Appl Pyrol. 1989;14(4):237-80.

39. Ramirez-Corredores MM. Chapter 6-Pathways and mechanisms of fast pyrolysis: impact on catalyst research. In: Kstal S, editor. The role of catalysis for the sustainable production of bio-fuels and bio-chemicals. Amsterdam: Elsevier; 2013. p. 161-216.

40. Łucejko JJ, Mattonai M, Zborowska M, Tamburini D, Cofta G, Cantisani E, et al. Deterioration effects of wet environments and brown rot fungus Coniophora puteana on pine wood in the archaeological site of Biskupin (Poland). Microchem J. 2018;138:132-46.

41. Tamburini D, Łucejko JJ, Pizzo B, Mohammed MY, Sloggett R, Colombini MP. A critical evaluation of the degradation state of dry archaeological wood from Egypt by SEM, ATR-FTIR, wet chemical analysis and Py(HMDS)GC-MS. Polym Degrad Stab. 2017;146:140-54.

42. Lucejko JJ, Tamburini D, Modugno F, Ribechini E, Colombini MP. Analytical pyrolysis and mass spectrometry to characterise lignin in archaeological wood. Appl Sci. 2021:11(1):240.

43. Browning BL. Methods of wood chemistry, vol. II. New York: Interscience Publishers; 1967.

44. TAPPI. Acid insoluble lignin in wood and pulp T 222 om-06. New York: Industry UTAoPaP; 2006.

45. TAPPI. Standards technical association of pulp and paper industry, New York; 1996-7.

46. Wise LE, Murphy M, D'Addieco AA. Chlorite holocellulose. Paper Trade J. 1946;122(2):35-43.

47. Hoffmann P, Jones MA. Structure and degradation process for waterlogged archaeological wood, archaeological wood. American Chemical Society; 1989. p. 35-65.

48. van Bergen PF, Poole I, Ogilvie TM, Caple C, Evershed RP. Evidence for demethylation of syringyl moieties in archaeological wood using pyrolysis-gas chromatography/mass spectrometry. Rapid Commun Mass Spectrom. 2000;14(2):71-9.

49. Kotz JC, Treichel P, Townsend JR. Chemistry \& chemical reactivity. 8th ed. Belmont: Mary Finch; 2011.

\section{Publisher's Note}

Springer Nature remains neutral with regard to jurisdictional claims in published maps and institutional affiliations.

\section{Submit your manuscript to a SpringerOpen ${ }^{\circ}$ journal and benefit from:}

- Convenient online submission

- Rigorous peer review

- Open access: articles freely available online

- High visibility within the field

- Retaining the copyright to your article

Submit your next manuscript at springeropen.com 